\title{
CORRESPONDENCE
}

\section{ON THE OCCURRENCE OF LINNAEITE IN THE COAL MEASURES OF SOUTH WALES}

SIR,-In 1928 the Geological Magazine published a note ${ }^{1}$ on linnaeite following a paper ${ }^{2}$ by Dr. F. J. North and the writer on the distribution of millerite in South Wales. The records of occurrence are, of course, of academic interest only. The more important significance is the light which the occurrence of these minerals throws on the source of the sediments deposited in what is now South Wales during Coal Measure times.

In the $1928^{1}$ paper, I remarked that the only previous record of Welsh linnaeite which I could find takes the form of a note (without title) by A. L. des Cloizeaux in a French publication. ${ }^{3}$ This record was based on a specimen from the "Rhonda" (Rhondda) discovered by a Mr. Terrill of Swansea, " which does not seem to have been preserved."

I visited the Museum d'Histoire naturelle in Paris and was most kindly received by Dr. Orcel, who gave me access to the reserve collections. I failed to find the specimen as it never occurred to me that it might still be in the collection made by Mr. Terrill.

In 1937 the Terrill collection of minerals was presented to the National Museum of Wales, but after ten years the name had no particular significance for me and it was not until 1951 when the collection was being critically examined that I discovered a specimen of linnaeite from South Wales and realized the Terrill who made the collection and the Terrill referred to by des Cloizeaux in 1880 were one and the same person.

The specimen in the Terrill collection is no better than those described in 1928, and it has no information giving the precise horizon and locality.

The specimen consists of separate crystals or aggregates of minute modified octahedra on dolomite or ankerite lining septarian cracks in clay ironstone.

I have now confirmed the occurrence in Wales of all the minerals found in similar circumstances in the clay ironstones of Bohemia with the exception of whewellite, hydrated calcium oxalate. The specimens kindly given to me for the National Museum of Wales by Professor Slavik from the Prago Mine, near Kladno, Bohemia, show the whewellite to be the last formed mineral and it way well be that the Bohemian mineral is of very recent origin, possibly associated with the decay of pitprops in abandoned workings.

\section{REFERENCES}

1. Howarth, W. E., 1928. On the Occurrence of Linnaeite in the Coal Measures of South Wales. Geol. Mag., lxv, 517-18.

2. North, F. J., and W. E. Howarth, 1928. On the Occurrence of Millerite and Associated Minerals in the Coal Measures of South Wales. Proc. South Wales Institute of Engineers, xliv, No. 3, 325-348.

3. Bulletin de la Société minéralogique de France, IIIe (1880), 170-1.

Assistant KeEPER of Geology,

W. E. HOWARTH.

National Museum of Wales, CARDIFF.

12th July, 1954.

\section{ANGLE BETWEEN THE PRINCIPAL HORIZONTAL STRESS AND TRANSCURRENT FAULTS}

SIR,-By a coincidence two papers recently published in the same number of the Geological Magazine (xci, 2) provide evidence that under some conditions the angle between the principal horizontal stress and transcurrent faults is about $60^{\circ}$ and not, as suggested by Anderson (1942, p. 14), always less than $45^{\circ}$. 
In Leedal and Walker's map (p. 118) of transcurrent faults cutting the Barnesmore Granite in Donegal the average strike of the dextral faults is $086^{\circ}$ and that of the sinistral faults $218^{\circ}$. If these faults were caused by the same stress conditions, the direction of the principal horizontal stress is $\frac{1}{2}\left(218^{\circ}+086^{\circ}\right)=152^{\circ}$, and the angle between the principal stress and the fault $\frac{1}{2}\left(218^{\circ}-086^{\circ}\right)=66^{\circ}$. Because this angle is greater than $45^{\circ}$, and without confirmatory evidence, Leedal and Walker concluded that the two sets of faults are of different ages.

A map presented by Auden (p. 98) shows dykes and two sets of shear (transcurrent) faults cutting Deccan lavas in Bombay State. If it is accepted with Anderson (p. 24) that the dykes lie in the general direction of the principal horizontal stress, then one of the sets can be distinguished as dextral and the other as sinistral, in spite of the fact that no displacements have been determined. The average strike of the dextral is $021^{\circ}$ and that of the sinistral $141^{\circ}$. The direction of principal horizontal stress is $\frac{1}{2}\left(141^{\circ}+021^{\circ}\right)=081^{\circ}$, and the angle between the principal stress and the faults $\frac{1}{2}\left(141^{\circ}-021^{\circ}\right)$ $=60^{\circ}$. The average strike of the dykes is $072^{\circ}, 9^{\circ}$ less than the strike of the horizontal principal stress determined from the faults.

The examples given have the disadvantage that being "fossil" faults it is difficult to prove that the dextral and sinistral members are parts of the same stress pattern. Active faults do not suffer from this disadvantage.

Two suitable pairs of active transcurrent faults are known in New Zealandthe Alpine and Moonlight faults (Wellman, 1953), and the Wellington and Baring Head faults-by a coincidence they give the same direction of stress and the same angle- $112^{\circ}$ and $57^{\circ}$.

The evidence from active major transcurrent faults in California is similar to that in New Zealand. The sinistral Big Pine and Garlock faults are intersected by the dextral San Andreas Fault (Hill and Dibblee, 1953), the stress directions being $354^{\circ}$ and $356^{\circ}$ and the angles $65^{\circ}$ and $68^{\circ}$.

The angles between the principal stress and the transcurrent faults are remarkably consistent and considerably in excess of the maximum value of $45^{\circ}$ suggested by Anderson from theory. It is suggested that observations be made over as wide a range of tectonic conditions as possible and an attempt then made to establish a more comprehensive theory.

\section{GeOLOGICAL SURVEY, \\ 156 THE TERRACE, \\ WELLINGTON C. 1 New Zealand. \\ 15 th July, 1954.}

H. W. Wellman.

\section{REFERENCES}

Anderson, J. G. C., 1942. The Dynamics of Faulting. Edinburgh.

AudEN, J. B., 1954. Erosional Patterns and Fracture Zones in Peninsular India. Geol. Mag., xci, 116-128.

LeEdAL, G. P., and G. P. L. WALKER, 1954. Tear Faults in the Barnesmore area, Donegal. Geol. Mag., xci, 116-128.

Hill, M. L., and T. W. Dibblee, 1953. San Andreas, Garlock, and Big Pine Faults, California. Bull. Geol. Soc. Amer., lxiv, 443-458.

Wellman, H. W., 1953. Data for the study of Recent and late Pleistocene Faulting in the South Island of New Zealand. N.Z. Journ. Sci. \& Tech., B, 34 (4), 271-288.

\section{MINERALS FOR THE CHEMICAL AND ALLIED INDUSTRIES}

SIR,-I deeply appreciate the general tenor of Professor Fearnsides's review (Geol. Mag., xcl, 1954, p. 334), of my recently published book, Minerals for the Chemical and Allied Industries, but would like to correct a misunderstanding. 